Вдовіченко Оксана

доктор психологічних наук, доцент кафедри теорії та методики практичної психології Державного закладу «Південноукраїнський національний педагогічний університет імені К. Д. Ушинського» https://orcid.org/0000-0003-0430-2295.

DOI https://doi.org/10.35619/praprv.v1i16.206

\title{
ПОРІВНЯННЯ СХИЛЬНОСТІ ДО РИЗИКУ В ПІДЛІТКОВОМУ ТА ЮНАЦЬКОМУ ВІЩ
}

Анотація. У роботі наведено результати теоретико-емпіричного дослідження особливостей прояву схильності до ризику у підлітковому та юнацькому вічі. Відзначено, щяо саме иі вікові періоди пов'язані із загостренням проблеми пошуку сенсу життя, зростанням невпевненості в собі, виникненням інтимних, особистісних та міжособистісних непорозумінь, що обумовлює збільшення кількості та вираженості ризикових дій у иих вікових групах. Ризик розглядається нами як специфічні емоційно-вольові дії, щуо активують різні психічні функиіі, які спрямовані на подолання невизначеної і небезпечної ситуації.

В емпіричному дослідженні було використано такі психодіагностичні інструменти: тест «Суб'єктивна оцінка ситуачій як небезпечних $i$ невизначених» (Вдовіченко, 2018), «Опитувальник схильність до ризику в різних сферах діяльності» (Вдовіченко, 2007), методика "Самооиінка схильності до екстремально-ризикованої поведінки» (Zuckerman, 2005), методика «Особистісні фактори прийняття рішення» (ОФР-25) (Корнілова, 1994), опитувальник якісних показників схильності до ризику (Саннікова, \& Бикова, 2008). Вибірку дослідження склали 897 досліджуваних підліткового та юнаџького віку 14-19 років (підлітки - 432 школяра, юнаки - 465 студентів).

Отримані результати дозволили встановити специфічні відмінності між експериментальними групами за показниками, щуо характеризують вираженість схильності до ризику. Так, у підлітків високі показники пошуку нових вражень, репрезентуються у прагненні змінювати себе, свій зовнішній вигляд, здійснювати необмірковані, імпульсивні, зокрема, й асочіальні вчинки. Вони схильні до демонстративних форм поведінки, які можуть набувати девіантних форм. Крім того, підлітки мають вищий ризик формування адикцій, ніж юнаки. Прагнення до подолання труднощів, пов'язане з високою імпульсивністю, агресивними проявами у поведінці, нехтуванням деталей у виконанні складної роботи, недостатньою довільністю у діяльності загалом, також більшою мірою властиве підліткам, ніж особам юнацького віку. У ситуаціях, пов'язаних з ризиком, юнаки є більш розсудливими, раціональними у виборі стратегій при їх виріменні, демонструють вищий рівень усвідомленості своїх вчинків.

Отримані результати виступають підгрунтям для продовження дослідження иіннісно-мотваційної сфериу підлітків та юнаків з різним рівнем вираженості схильності до ризику, а також особливостей реалізаџії ними ризикової поведінки з урахуванням також гендерних характеристик.

Ключові слова: ризик, психологія ризику, схильність до ризику, готовність до ризику, вираженість схильності до ризику, підліток, юнащький вік.

Постановка проблеми. В умовах трансформації суспільства молода особистість 3 характерними для неї емоційної нестійкістю, імпульсивністю частіше потрапляє в небезпечні, екстремальні ситуації, які супроводжуються ризикованими діями. Перешкоди, які стають на заваді досягненню життєвих цілей, реалізації мрій і видаються нездоланними, змушують молодих людей шукати вихід, переосмислювати сенс буття. Саме у підлітковому 
й юнацькому віці загострюється проблема пошуку сенсу життя, зростає невпевненість в собі, виникають інтимні, особистісні та міжособистісні непорозуміння.

Аналіз останніх досліджень 3 проблеми. На думку ряду фахівців (Башкіна \& Посохова , 2007; Хомуленко \& Абсалямова, 2011; Ільїн, 2012) та ін.) підлітковий період характеризується значною кількістю ситуацій, які можна віднести до розряду ризикованих. Саме перехід на новий рівень психічного розвитку зумовлює зростання кількості невиправданих ризикованих вчинків, які негативно впливають на особистісний розвиток і психічне здоров'я підлітків.

Основні причини інтенсифікації ризикової поведінки у підлітків умовно поділяють на дві групи: потреба в гострих (нових) відчуттях (Цукерман, 2005) та фізіологічні особливості (Дегтяренко, Cloninger, Gottesman та ін.). Так, Башкіна \& Посохова (2007) вважають, що підліткам притаманна потреба в переживанні ризику, яка проявляється в єдності двох протилежних тенденцій - в конструктивній соціально прийнятній активності з підвищеним ризиком або в деструктивній, зокрема, в саморуйнівній діяльності. Отже, наявність почуття ризику, з одного боку, дає можливість просування шляхом саморозкриття, а 3 іншого нівелює світовідчуття, навіть призводить до балансування на межі життя і смерті. Іншою важливою умовою вибору ризикових форм активності у підлітків $є$ присутність однолітків. За думкою науковців, це пов'язано з незрілістю нейронних зв'язків, що відповідають за процес оцінки та аналізу ситуації. Така незрілість зумовлює труднощі або навіть неможливість ухвалення зважених, розумних рішень в емоційно насиченій ситуації у присутності однолітків (Ільїн, 2012). Так, Пузиревич, досліджуючи ризиковану поведінку молоді, запропонувала модель iї формування, де розглядаються стратегії реалізації ризикованої поведінки молодих людей з позицій сприйняття їх ставлення до себе з боку оточуючих, наявного сенсу життя й ціннісних орієнтацій. Результати роботи свідчать, що чим вище ступінь наповненості сенсом життя молодих осіб, тим вірогіднішим є формування у них конструктивної поведінки, і навпаки - чим нижче ступінь наповненості, тим вище вірогідність аутодеструктивної поведінки (Пузиревич, 2009).

Цікавою виступає альтернативна модель, яка засвідчує, що підлітки йдуть на ризик 3 метою дослідження світу та накопичення досвіду, який дозволить їм краще справлятися в майбутньому з важким завданням прийняття рішень типу «Чи слід мені йти на цю роботу?» «Чи слід вступати в шлюб з цією людиною?» Таким чином, альтернативна модель пояснює помітне збільшення ризиків, на які йдуть підлітки, «адаптивної потребою набуття досвіду, який потрібно для дорослих ролей i дорослої поведінки» (Romer, Reyna, \& Satterthwaite, 2017). Стосовно юнацького віку визначено, що 50\% осіб даного вікового періоду мають високу схильність до ризику, а в процесі дорослішання вона знижується. Схильність до ризику юнацтва пов'язана 3 їх орієнтованістю на майбутнє, прагненням нав'язати світу власний порядок, намаганням вийти за межі структур, що склалися. I часто молоді люди ризикують через відсутність передбачення можливих наслідків, нехтують небезпекою, не враховують міру ефективності ризику (Ніазашвілі, 2007).

Отже, теоретичний огляд сучасного стану розроблення даної проблематики показав, що існує недостатня кількість досліджень щодо виявлення специфіки схильності до ризику між підлітками та юнаками.

Мета статті полягає у досліджені вікових відмінностей у схильності до ризику в підлітковому та юнацькому віці.

Виклад основного матеріалу дослідження. Відзначимо, що вітчизняними i зарубіжними вченими проводилися теоретичні й емпіричні психологічні дослідження, спрямовані на вивчення змісту феномену ризику і його основних конструктів у осіб підліткового і юнацького віку:

Цікавим виступають результати дослідження Казанжи (2015), у яких відзначено, що у курсантів (спеціалізація «Судноводіння на морських шляхах») такі особистісні характеристики як готовність до ризику, уміння вирішувати конфліктну ситуацію, стресостійкість, прийняття себе та інших, емоційний комфорт, внутрішній контроль, 
контактність, самоприйняття, гнучкість поведінки, товариськість, креативність, сміливість тощо відіграють значну роль у психологічній готовності до діяльності у складних умовах.

Також у дослідженнях підкреслюється, що підлітковий та юнацький вік загалом характеризується меншою раціональністю та певною мірою нижчою готовністю до ризику. Висока міра імпульсивності більшою мірою властива підлітковому віку, що відмічалася також в інших дослідженнях (Хомуленко \& Абсалямова, 2011). Як ми бачимо наведені дослідження показують специфічні особливості вираженості ризику і його складових в залежності від фаху, віку, психологічних ресурсів особистості. Спираючись на результати наших досліджень (Вдовіченко, 2019) будемо дотримуватися розуміння ризику як специфічної емоційно-вольової дії, що активує різні психічні функції, які спрямовані на подолання невизначеної і небезпечної ситуації. Ризик як психологічний феномен має структурний характер i включає в себе відповідну ситуацію, іiі оцінку, ступінь іiі усвідомленості суб'єктами, фактори ризику; ситуацію його вибору, межі і зони ризику.

Особистість, опинившись в умовах ситуації ризику проходить певний циклічний процес: сприймання та суб'єктивну оцінку ситуації, обумовлену особливостями схильності і готовності до ризику та психологічними чинниками особистості, яка може ії прогнозувати на рівні власної поведінки чи вчинку; прийняття рішення імпульсивного чи рефлексивного щодо вибору моделі поведінки з потенційного шаблонного репертуару, який пов'язаний із ситуаціями того типу; реалізація рішення у конструктивній формі ризикового вчинку чи у деструктивному при реалізації ризикових дій; рефлексія результатів вчинку (дії, поведінки) внаслідок функціонування механізму зворотного зв'язку, яка обумовлює раціональний чи емоційний (ірраціональні прагнення до переживання певних емоцій) шлях фіксації ризику особистості та визначення характеру суб’єктивної оцінки ситуацій небезпеки та ін.

Циклічна структурно-процесуальна модель ризику відображує реальне перебування особистості в умовах ситуації небезпеки та невизначеності та демонструє міру іiї активності, як суб'єкта поведінки в даній ситуації. Структуризацію процесу проходження особистості через етапи розгортання ситуації ризику здійснено нами з урахуванням надбань психології прийняття рішень, психології вчинку, психології рефлексії та психології особистості. Виділені в побудованій моделі чинники ризику (когнітивні, афективні, мотиваційнорегулятивні, конативні) дають можливість системно підійти до його пізнання.

3 урахуванням дослідження змісту ризику як психологічного феномену та його чинників нами було обрано комплекс психодіагностичних методик. При їх розробці, адаптації ми спиралися на ті, які отримали певне поширення для дослідження ризику в експериментальній психології. При цьому виходили з того, щоб дані методики були, поперше, валідними; по-друге, відповідали віковим особливостям; по-третє, давали можливість оцінити рівень вираженості ризику. Нами був побудований власний тест «Суб'єктивна оцінка ситуацій як небезпечних і невизначених» (Вдовіченко, 2018), що містить 10 ситуацій, в яких означено міру невизначеності та небезпеки та передбачає 5 варіантів відповідей. Максимально висока оцінка складає 40 балів, мінімальна - 0 балів.

Надійність опитувальника перевірялась через розрахунок статистики альфа Кронбаха для шкали, що включає всі 10 пунктів. Показник альфа Кронбаха для шкали із 10 запитань склав 0,793 i який $є$ більшим $0,7 \mathrm{t}$ (мінімальний припустимий показник). Ретестова надійність опитувальника. Ре-тест здійснювався на вибірці у 100 респондентів з інтервалом в 1 місяць. Кореляція між результатами першого та повторного тестування становила $\mathrm{r}=0,862$, що свідчить про високу ретестову надійність опитувальника.

Також ми використали авторський опитувальник «Схильність до ризику в різних сферах життєдіяльності» (Вдовиченко, 2007), що спрямований на дослідження рівня схильності до ризику у таких сферах життєдіяльності, як побутова, міжособистісна, просторова, а також сфера здоров'я. Опитувальник має 40 запитань 3 трьома варіантами відповідей на кожне, які дозволяють визначити вираженість схильності до ризику. Загальний показник схильності до ризику має такі рівні: 0-16 балів - низький, 17-28 балів - помірний, 29-37 - середній, 38-44 - підвищений і понад 45 балів - критичний. 
Методика «Самооцінка схильності до екстремально-ризикованої поведінки» (Zuckerman, 2005) спрямована на визначення таких компонентів схильності особистості до ризику, як пошук гострих відчуттів, непереносимість одноманітності, пошук нових вражень, неадаптивне прагнення до труднощів. Методика складається 340 тверджень 3 типовими варіантами відповідей за шкалою Лайкерта. Максимальна кількість балів за кожною шкалою -10 .

Методика «Особистісні фактори прийняття рішення» (ОФР-25) (Корнілова, 1994) дозволяє визначити такі тенденції ризику особистості, як раціональність (максимальна кількість балів - 12) та готовність до ризику (максимальна кількість балів - 13).

Опитувальник якісних показників схильності до ризику (Саннікова, \& Бикова, 2008) спрямований на визначення рівня вираженості таких компонентів схильності до ризику, як емоційний, когнітивний, конативний, контрольно-регулятивний, а також загального показника схильності до ризику. Опитувальник містить 40 питань (по 10 на кожну шкалу). Обчислення індивідуальних оцінок полягає в підсумовуванні набраних балів за кожним 3 параметрів. Максимально висока оцінка за кожною шкалою складає 40 балів, мінімальна - 0 балів. Використання перерахованих методик дозволило виявити і кількісно оцінити, поперше, показники, що визначають певні аспекти схильності до ризику: П1 - суб'єктивна оцінка ситуацій як небезпечних і невизначених; П2 - раціональність; П3 - готовність до ризику; П4 - пошук гострих відчуттів; П5 - непереносимість одноманітності; П6 - пошук нових вражень; П7 - неадаптивне прагнення до труднощів.

По-друге, показники, що характеризують ранг вираженості ризику в побутовій сфері (П8); сфері здоров'я (П9); просторовій сфері (П10); міжособистісній сфері (П11).

По-третє, якісні показники схильності до ризику П12 - емоційний; П13 -когнітивний; П14 - конативний; П15 - контрольно-регулятивний.

Означені показники схильності до ризику визначалися за допомогою комплексу психодіагностичних інструментів, який містив самооціночні тести з вибором певної відповіді та опис конкретних ситуацій з варіантами обрання їх вирішення (чи власної поведінки).

Вибірку дослідження склали 897 досліджуваних підліткового та юнацького віку 14-19 років (підлітки - 432 школяра, юнаки - 465 студентів).

Результати поглибленого статистичного аналізу показали, що у вікових групах підлітків та юнаків відзначено певні специфічні відмінності (див. табл. 1).

Таблиия 1

Статистично достовірні відмінності показників, щцо характеризують виражсеність схильності до ризику у підгрупах підлітків та юнаків

\begin{tabular}{|c|c|c|c|c|c|c|c|c|c|c|c|c|c|c|}
\hline \multirow{3}{*}{$\begin{array}{c}\text { Статистич } \\
- \\
\text { ні критерії }\end{array}$} & \multicolumn{14}{|c|}{$\begin{array}{l}\text { Показники схильності до ризику респондентів підліткового і } \\
\text { юнацького віку }\end{array}$} \\
\hline & \multicolumn{2}{|c|}{ П1 } & \multicolumn{2}{|c|}{$\Pi 2$} & \multicolumn{2}{|c|}{$\Pi 3$} & \multicolumn{2}{|c|}{ П4 } & \multicolumn{2}{|c|}{ П5 } & \multicolumn{2}{|c|}{ П6 } & \multicolumn{2}{|c|}{$\Pi 7$} \\
\hline & $\Pi$ & Ю & П & Ю & $\Pi$ & ю & $\Pi$ & ю & П & ю & $\Pi$ & Ю & $\Pi$ & Ю \\
\hline $\mathrm{X}$ & $\begin{array}{c}30,4 \\
2\end{array}$ & $\begin{array}{c}31, \\
1\end{array}$ & $\begin{array}{l}7 \\
67\end{array}$ & $\begin{array}{c}8,2 \\
5\end{array}$ & $\begin{array}{c}9,7 \\
9\end{array}$ & $\begin{array}{c}11,2 \\
3\end{array}$ & $\begin{array}{c}5,3 \\
0\end{array}$ & $\begin{array}{c}3,2 \\
5\end{array}$ & $\begin{array}{c}4,3 \\
2\end{array}$ & $\begin{array}{c}5,5 \\
6\end{array}$ & $\begin{array}{c}6,5 \\
0\end{array}$ & $\begin{array}{c}4,3 \\
6\end{array}$ & $\begin{array}{c}5,3 \\
5\end{array}$ & $\begin{array}{l}4, \\
02\end{array}$ \\
\hline$\delta$ & 8,09 & $\begin{array}{c}9,0 \\
5\end{array}$ & $\begin{array}{l}1 \\
98\end{array}$ & $\begin{array}{c}2,0 \\
5\end{array}$ & $\begin{array}{c}2,0 \\
8\end{array}$ & 3,65 & $\begin{array}{c}1,8 \\
5\end{array}$ & $\begin{array}{c}1,0 \\
5\end{array}$ & $\begin{array}{c}1,0 \\
2\end{array}$ & $\begin{array}{c}1,4 \\
3\end{array}$ & $\begin{array}{c}1,6 \\
8\end{array}$ & $\begin{array}{c}1,0 \\
1\end{array}$ & $\begin{array}{c}1,6 \\
5\end{array}$ & $\begin{array}{l}1, \\
23\end{array}$ \\
\hline 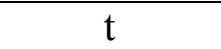 & \multicolumn{2}{|c|}{9,04} & \multicolumn{2}{|c|}{9,85} & \multicolumn{2}{|c|}{1,37} & \multicolumn{2}{|c|}{10,55} & \multicolumn{2}{|c|}{11,42} & \multicolumn{2}{|c|}{12,19} & \multicolumn{2}{|c|}{9,01} \\
\hline $\mathrm{P}<$ & \multicolumn{2}{|c|}{0,0001} & \multicolumn{2}{|c|}{0,0001} & \multicolumn{2}{|c|}{ 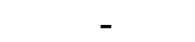 } & \multicolumn{2}{|c|}{0,0001} & \multicolumn{2}{|c|}{0,0001} & \multicolumn{2}{|c|}{0,0001} & \multicolumn{2}{|c|}{0,0001} \\
\hline
\end{tabular}

Стьюдента.

У процесі аналізу показника П1, нами встановлено, що у підлітки мають вищий рівень толерантності до ризику. Запропоновані у тесті ситуації підлітки оцінюють як менш загрозливі, небезпечні та невизначені у порівнянні 3 досліджуваними юнаками. Такі результати загалом в певній мірі узгоджуються 3 іншими дослідженнями ризику у підлітковому віці (Заика, 1990); (Кулагина, \& Колюцкий, 2001); (Хомуленко, \& 
Абсалямова, 2011), в яких цей період позиціонується як сенситивний щодо вираженості схильності до ризику та прояву ризикової поведінки.

Таким чином, за результатами методики «Суб'єктивна оцінка ситуацій як небезпечних і невизначених» виявлено, що підлітки загалом більш толерантно ставляться до нових, складних чи проблемних життєвих обставин, а ті ситуації, які можуть розцінюватись юнаками як небезпечні, для підлітків є більш допустимими, прийнятними.

За результатами нашого дослідження, раціональність (П2) та готовність до ризику (П3) як конструктивна форма його подолання більш притаманна юнакам. Це ми пояснюємо тим, що оскільки з віком особистість набуває більшої варіативності, диференційованості стратегій та здатностей до ефективного вирішення складних і невизначених ситуацій в силу більшого життєвого досвіду. Також виявлено, що підлітки більш схильні до екстремальної поведінки. Особливого значення для них набуває прагнення до нових вражень (П6), вони проявляють низьку толерантність до одноманітності у житті (П5). Крім того вони загалом більшою мірою схильні шукати труднощі та проблеми (П7), ніж представниками юнацького віку. Цілком очевидним виявляється і перевищення показників пошуку гострих вражень (П4) у підлітків у порівнянні з юнаками.

Отримані дані дають підставу відмітити, що підлітки більшою мірою схильні до екстремальних розваг (занурення з аквалангом, туристичні подорожі у гори, стрибки 3 парашутом тощо), ніж особи юнацького віку. Вони також очевидно в силу меншого життєвого досвіду недостатньо усвідомлюють небезпечність екстремальної поведінки (спорту та розваг), ніж більш досвідчені юнаки. Крім того, вікові особливості підлітків сприяють більшій готовності йти на ризик заради розваг, нових вражень, самоствердження тощо. Цікаво відзначити, що з віком зростає толерантність до монотонної діяльності, виконання рутинних обов'язків, повторного здійснення різних актів поведінки та вчинків. В цьому плані підлітки частіше уникають нудних співрозмовників, запобігають рутинній діяльності, нехтують непривабливими справами, навіть якщо вони є необхідними, ніж особи юнацького віку. Крім того молодь мріє про ідеальні умови праці, не усвідомлюючи складність оволодіння професійними компетентностями та всіх труднощів професійного та кар'єрного зростання. 3 віком особистість стає більш відповідальною, виявляє вищу довільність у виконанні складних та рутинних обов'язків.

Результати поглибленого статистичного аналізу показали, що у вікових групах підлітків та юнаків відзначено відмінності ризику у різних сферах діяльності (див. табл. 2).

Табличя 2

\section{Статистично достовірні відмінності показників, щц характеризують вираженість ризику у різних сферах діяльності}

\begin{tabular}{|c|c|c|c|c|c|c|c|c|}
\hline \multirow[t]{3}{*}{$\begin{array}{l}\text { Статистич- } \\
\text { ні критерії }\end{array}$} & \multicolumn{8}{|c|}{$\begin{array}{c}\text { Показники схильності до ризику респондентів підліткового і } \\
\text { юнацького віку у різних сферах діяльності }\end{array}$} \\
\hline & \multicolumn{2}{|c|}{ П8 } & \multicolumn{2}{|c|}{$\Pi 9$} & \multicolumn{2}{|c|}{ П10 } & \multicolumn{2}{|c|}{ П11 } \\
\hline & $\Pi$ & Ю & $\Pi$ & Ю & $\Pi$ & ю & $\Pi$ & Ю \\
\hline $\mathrm{X}$ & 6,70 & 4,12 & 5,90 & 5,05 & 7,14 & 8,90 & 10,40 & 9,01 \\
\hline$\delta$ & 2,18 & 1,75 & 2,17 & 1,98 & 2,25 & 3,72 & 3,70 & 2,56 \\
\hline $\mathrm{t}$ & \multicolumn{2}{|c|}{11,62} & \multicolumn{2}{|c|}{9,62} & \multicolumn{2}{|c|}{10,25} & \multicolumn{2}{|c|}{10,31} \\
\hline $\mathrm{P}<$ & \multicolumn{2}{|c|}{0,0001} & \multicolumn{2}{|c|}{0,0001} & \multicolumn{2}{|c|}{0,0001} & \multicolumn{2}{|c|}{0,0001} \\
\hline
\end{tabular}
Стьюдента.

3 отриманих результатів видно, що підлітки є більш ризиковими у сфері побуту (П8), сфері здоров'я (П9) та міжособистісній сфері (П11). У юнацькому віці спостерігається більша вираженість схильності у просторовій сфері (П10).

Як наслідок, очевидно підлітки частіше використовують ушкоджені пристрої та рідше перевіряють їх справність. В той же час серед юнаків $\epsilon$ певна кількість власників 
автотранспорту, а усвідомлення того, що від справності особистого транспорту залежить як власне життя та здоров'я, так й інших, обумовлює більшу відповідальність та обережність у його використанні, ніж у підлітків. При цьому підліткам більшою мірою, ніж представникам юнацького віку, притаманні ризикові прояви у спілкуванні з іншим людьми. Така ризикованість може проявлятись у небезпечних розвагах та сумісному дозвіллі 3 однолітками. Загалом соціальна ситуація розвитку у період підліткового віку передбачає розширення міжособистісних контактів і зв'язків, серед яких можуть бути випадкові та сумнівні. Інфантильність підлітків, які обумовлені соціальною залежністю від батьків, відсутність життєвого досвіду та більша відкритість світу очевидно визначає їх схильність до ризику у міжособистісній сфері. Підлітковий вік, крім того, є сенситивним для виникнення залежності від різних субкультур.

Юнаки загалом є більш активними мандрівниками та спортсменами у порівнянні 3 особами підліткового віку. Вони частіше відважуються на ризикові подорожі та спортивні захоплення.

Результати поглибленого статистичного аналізу показали, що у вікових групах підлітків та юнаків відзначено відмінності якісних показників ризику (див. табл. 3).

Таблиия 3

Статистично достовірні відмнності якісних показників ризику у підлітків та юнаків

\begin{tabular}{|c|c|c|c|c|c|c|c|c|}
\hline \multirow{3}{*}{$\begin{array}{l}\text { Статистич- } \\
\text { ні критерії }\end{array}$} & \multicolumn{8}{|c|}{ Показники } \\
\hline & \multicolumn{2}{|c|}{$\Pi \Pi 12$} & \multicolumn{2}{|c|}{ П13 } & \multicolumn{2}{|c|}{$\Pi$ П14 } & \multicolumn{2}{|c|}{$\Pi 15$} \\
\hline & $\Pi$ & ю & $\Pi$ & ю & $\Pi$ & ю & $\Pi$ & ю \\
\hline $\mathrm{X}$ & 28.93 & 25.65 & 20.25 & 24,33 & 28.00 & 23.25 & 20,02 & 23,49 \\
\hline$\delta$ & 5,07 & 4,02 & 3,52 & 5,77 & 5,01 & 3,56 & 2,10 & 3,66 \\
\hline $\mathrm{t}$ & \multicolumn{2}{|c|}{3,48} & \multicolumn{2}{|c|}{7,62} & \multicolumn{2}{|c|}{5,65} & \multicolumn{2}{|c|}{9,21} \\
\hline $\mathrm{P}<$ & \multicolumn{2}{|c|}{0,001} & \multicolumn{2}{|c|}{0,0001} & \multicolumn{2}{|c|}{0,001} & \multicolumn{2}{|c|}{0,0001} \\
\hline
\end{tabular}

Примітки: п - підлітки; ю - юнаки; X - середнє значення, $\delta$ - стандартне відхилення, t-критерій Стьюдента.

За емоційним (П12) та конативним (П14) компонентами ризику у підлітків виявлено більш високі показники, ніж у юнаків. Досліджуванні підліткового віку частіше виявляють позитивне емоційне збудження та менший страх у ситуаціях ризику, визначають їх привабливість для себе, також їм частіше подобається втягуватися в небезпечні ситуації, демонструвати себе як сміливу людину. Юнаки перевищують у когнітивному (П13) та контрольно-регулятивному (П15) показниках досліджуваних підлітків.

Аналізуючи якісні показники ризику визначено, що підлітки частіше довіряють незнайомим людям, менш розсудливі, більше покладаються на випадкову вдачу, віддають перевагу азарту, діють навмання.

Висновки і перспективи подальших розвідок. Таким чином, аналізуючи результати дослідження виявлено:

- по-перше, існує недостатня кількість досліджень щодо виявлення специфіки ризику між підлітками та юнаками;

- по-друге, саме у підлітковому й юнацькому віці загострюється проблема пошуку сенсу життя, зростає невпевненість в собі, виникають інтимні, особистісні та міжособистісні непорозуміння і все це впливає на більш виражені ризиковані дій у визначених вікових груп;

- по-третє, в наших дослідженнях, особистість, опиняючись в умовах ситуації ризику проходить через циклічний процес, що включає: сприймання та суб'єктивну оцінку ситуації; прийняття рішення імпульсивного чи рефлексивного; реалізація рішення у конструктивній формі ризикового вчинку чи у деструктивному здійсненні ризикових дій; рефлексія результатів вчинку (дії, поведінки);

- по-четверте, відзначено певні специфічні відмінності за показниками, що характеризують вираженість ризику. Так, у підлітків високі показники пошуку нових 
вражень, репрезентуються у прагненні змінювати себе, свій зовнішній вигляд, здійснювати необмірковані безшабашні, зокрема, й асоціальні вчинки, також вони схильні до девіантної поведінки, до дромоманії, демонстративних форм поведінки, та мають вищий ризик формування адикцій, ніж у юнаків. Прагнення до труднощів, що характеризується високою імпульсивністю, агресивними проявами у поведінці, нехтуванням деталей у виконанні складної роботи, недостатньою довільністю у діяльності загалом, властиве більшою мірою також підліткам, ніж особам юнацького віку;

- по-п’яте, відзначено відмінності ризику у різних сферах діяльності: більш життєвий досвід юнаків, ніж у підлітків виступає умовою наявності раціонального підходу до вибору контактів, меншої залежності від соціальних мереж (в яких імовірність та невизначеність у стосунках обумовлена самим форматом веб-мереж), випадкових знайомств на вулиці та закладах дозвілля тощо. Юнаки більше проявляють ризик в просторовій сфері, що пов'язані з пересуванням та активністю: перевищення швидкості на автомобілі, їзда на мотоциклах та мопедах, екстремальні види спорту, подорожування у гори, походи на байдарках тощо;

- по-шосте, за якісними показниками ризику визначено, що за емоційним (П12) та конативним (П14) компонентами ризику у підлітків виявлено більш високі показники, ніж у юнаків. А саме, підлітки частіше здатні відкрито чинити опір тим, хто їх образив, спроможні йти на конфлікт, чинити необмірковано, імпульсивно. За когнітивним (П13) та контрольнорегулятивном (П15) показникам юнаки перевищують досліджуваних підлітків. Юнаки у ситуаціях ризику є більш розсудливими, раціональними у виборі стратегій при їх вирішенні, усвідомлюють свої вчинки.

Отримані результати виступають підгрунтям для продовження дослідження цінностей та мотивів у підлітків та юнаків з певним рівнем схильності до ризику, а також його особливостей з урахуванням їх гендерних розрізнень.

\section{СПИСОК ПОСИЛАНЬ}

Башкина, Ю. Д., \& Посохова, С. Т. (2007). Личностный смысл чувства риска у подростков. Ананьевские чтения-2007: материаль научно-практической конференции.

Вдовиченко, О. В. (2007). Апробация опросника склонности к риску в различных сферах деятельности. Науковий часопис НПУ імені М. П. Драгоманова. Психологічні науки, 17 (41), I, 66-69.

Вдовіченко, О. В. (2018). Тест суб'єктивної оцінки ситуацій як невизначених/небезпечних. Харківський осінній марафон психотехнологій: матеріали науково-практичної конферениії. Харків: Діса плюс, 21-22.

Вдовіченко, О. В. (2019). Психологія ризику особистості. Одеса: ФОП Бондаренко М. О.

Заика, Е. В. (1990). Психологическая характеристика личности подростков с отклоняющимся поведеним. Вопросы психологии, 4, 83-91.

Ильин, Е. П. (2012). Психология риска. Санкт-Петербург: Питер.

Казанжи, М. Й. (2015). Психологічна готовність до діяльності у складних умовах. Наукові записки Національного університету “Острозька академія”. Психологія, 2, 65-73.

Корнилова, Т. В. (1994). Диагностика “личностных факторов” принятия решений. Bonpocbl психологии, 6, 99-109.

Кулагина, И. Ю., \& Колюцкий, В.Н.(2001). Возрастная психология: Полный жсизненный цикл развития человека. Москва: ТЦ “Сфера”.

Ниазашвили, А.Г. (2007). Индивидуальные различия склонности к риску в разных социальных ситуачиях развития личности. (Автореф. дис. канд. психол. наук). Московский гуманитарный университет, Москва.

Пузыревич, Н. Л. (2009). Модель формирования рискованного поведения в старшем подростковом воздасте. Психологический журнал, 4, 96-101.

Саннікова, О. П., \& Бикова, С. В. (2008). Психологічна діагностика стійкої схильності до ризику: апробація оригінальної методики. Проблеми гуманітарних наук. Наукові 
записки Дрогобицького державного педагогічного університету імені I. Франка. Психологія, 19, 4-15.

Хомуленко, Т. Б., \& Абсалямова, Л. М. (2011). Мотивачійні, інтелектуальні та емочійні компоненти психології ризику: віковий аспект. Харків: ХНПУ.

Romer, D., Reyna, V. F., \& Satterthwaite, T. D. (2017). Beyond stereotypes of adolescent risk taking: Placing the adolescent brain in developmental context. Developmental Cognitive Neuroscience, 27, 19-34.

Zuckerman, M. (2005). Psychobiology of Personality. New York: Cambridge University Press.

\section{REFERENCES}

Bashkina, YU. D., \& Posokhova, S. T. (2007). Osobystisnyy sens pochuttya ryzyku u pidlitkiv [Personal sense of risk senses in adolescents]. Anan'yivs'kyy chytannya-2007: materialy naukovo-praktychnoyi konferentsiyi. [in Russian].

Vdovychenko, O. V. (2007). Aprobatsiya opytuval'nyka skhyl'nosti do ryzyku v riznykh sferakh diyal'nosti [Approbation of the risk appetite questionnaire in various fields of activity]. Naukovyy chasopys NPU imeni M. P. Drahomanova. Psikholoichni nauky, 17 (41), ch. I, 66-69. [in Russian].

Vdovichenko, O. V. (2018). Test sub'yektyvnoyi otsinky sytuatsiy yak nevyznachennosti/nebezpechna [Test of subjective assessment of situations as uncertain/dangerous]. Kharkivs'kyy osinniy marafon psikhotekhnolohiy: materialy naukovo-praktychnoyi konferentsiyi. Kharkiv: DISA plyus, 21-22. [in Ukrainian].

Vdovichenko, O. V. (2019). Psykholohiya ryzyky osobystosti: monohrafiya [Psychology of personality risk]. Odesa: FOP Bondarenko M.O. [in Ukrainian].

Zayika, E. V. (1990). Psykholohichna kharakterystyka osobystosti pidlitkiv z povedinkoyu, shcho vidkhylyayet'sya [Psychological characteristics of the personality of adolescents with deviant behavior]. Pytannya psykholohiyi, 4, 83-91. [in Russian].

Il'yin, E. P. (2012). Psykholohiya ryzyku [Risk psychology]. Sankt-Peterburh: Piter. [in Russian].

Kazanzhy, M. Y. (2015). Psykholohichna hotovnist' do diyal'nosti u skladnykh umovakh [Psychological readiness to work in difficult conditions]. Naukovi zapysky Natsional'noho universytetu "Ostroz'ka akademiya". Psykholohiya, 2, 65-73. [in Ukrainian].

Kornilova, T. V. (1994). Diagnostika "lichnostnykh faktorov" prinyatiya resheniy [Diagnostics of "personal factors" of decision-making]. Voprosy psikhologii, 6, 99-109. [in Russian].

Kulahina, I. YU., Kolyutskyy, V. N. (2001). Vikova psykholohiya: Povnyy zhyttyevyy tsykl rozvytku lyudyny [Developmental Psychology: The Complete Life Cycle of Human Development]. Moskva: TTS “Sfera”. [in Russian].

Niazashvili, A. H. (2007). Indyvidual'ni vidminnosti skhyl'nosti do ryzyku v riznykh sotsial'nykh sytuatsiyakh rozvytku osobystosti [Individual differences in risk appetite in different social situations of personality development]. (Avtoref. dys. kand. psykhol. nauk). Moskovs'kyy humanitarnyy universytet. Moskva. [in Russian].

Puzyrevich, N. L. (2009). Model' formuvannya ryzykovanoyi povedinky v starshomu pidlitkovomu viddast' [Model of the formation of risky behavior in older adolescents]. Psykholohichnyy zhurnal, 4, 96-101. [in Russian].

Sannikova, O. P., \& Bykova, S. V. (2008). Psykholohichna diahnostyka stiykoyi skhil'nosti do ryzyko: aprobatsiya orihinal'noyi metodyky [Psychological diagnosis of persistent risktaking: testing of the original method]. Problemy humanitarnykh nauk. Naukovi zapysky Drohobyts'koho derzhavnoho pedahohichnoho universytetu imeni I. Franka. Psykholohiya, 19, 4-15. [in Ukrainian].

Khomulenko, T. B., \& Absalyamova, L. M. (2011). Motivatsiyni, intelektual'ni ta emotsiyni komponenty psykholohiyi ryzyky: vikoviy aspekt [Motivational, intellectual and emotional components of risk psychology: age aspect]. Kharkiv: KHNPU. [in Ukrainian].

Romer, D., Reyna, V. F., \& Satterthwaite, T. D. (2017). Beyond stereotypes of adolescent risk taking: Placing the adolescent brain in developmental context. Developmental Cognitive Neuroscience, 27, 19-34. [in English].

Zuckerman, M. (2005). Psychobiology of Personality. New York: Cambridge University Press. [in English]. 
COMPARISON OF RISK TOLERANCE IN EARLY AND LATE ADOLESCENCE

\author{
Oksana Vdovichenko \\ Doctor of psychological sciences, associate professor, \\ The State institution «South Ukrainian National Pedagogical University \\ named after K. D. Ushynsky», \\ https://orcid.org/0000-0003-0430-2295.
}

DOI https://doi.org/10.35619/praprv.v1i16.206

\begin{abstract}
The research shows the results of theoretical and empirical study of certain differences of indicators in tendency to risks tolerance among adolescents and young people. It is noted that in such periods of life as adolescence and youth, the problem of finding the sense in life intensifies, self-doubt grows, intimate issues appear, personal and interpersonal misunderstandings arises, and all these features cause significant risky actions in certain age groups. We consider risk being a set of specific emotional and volitional actions which activate various mental functions, which can be done during uncertain and dangerous situations.

The following psychodiagnostical tools were used in the empirical study: test «Subjective assessment of situations as dangerous and indeterminate» (by Vdovichenko, 2018), «Questionnaire risk propensity in different areas of activity» (by Vdovichenko, 2007), method of «Self-assessment of susceptibility for extreme risky behavior» (by Zuckerman, 2005), the method of «Personal decision-making factors»(OFR-25) (by Kornilova, 1994), a questionnaire of qualitative indicators of predisposition to risk (by Sannikova, \& Bykova, 2008). The study sample consisted 897 subjects of adolescences and adolescences aged 14-19 years (adolescents - 432 students, boys - 465 students).
\end{abstract}

There are some specific differences in the indicators that characterize the severity of risk. Thus, adolescents have higher rates of finding new impressions, and these rates are represented in the desire to change themselves, their appearance, commit reckless, including antisocial acts, they also tend to show interest in deviant and demonstrative kinds of behavior, there is a higher risk of addiction comparing with adolescents. The pursuit for difficulties, which is characterized by high impulsiveness, aggressive behavior, neglecting the details in the possible performance of complicated work, lack of arbitrariness in activities in general, is also a bigger characteristic of adolescents than adolescents.

Also, young people are more prudent in challenging environment, and also rational in choosing strategies for solving it. They are more likely to be aware of their actions. The obtained results serve as a basis for further researches of values and motives among adolescents and young people with a certain level of risk, as well as its features, and their gender differences are also taken into consideration.

Key words: risk, psychology of risk, propensity to risk, readiness to risk, severity of risk, adolescent, youth. 